\title{
THE GLYCINE SYNTHESIS IN PATIENTS WITH PROGRESSIVE MUSCULAR DYSTROPHY
}

\author{
By AXEL THOMSEN \\ (From the Institute of Medical Physiology, Copenhagen, Denmark)
}

(Received for publication October 16, 1936)

In 1929 Brand, Harris, Sandberg and Ringer (3) demonstrated that in patients with progressive muscular dystrophy, they could raise the excretion of creatine in the urine, characteristic of these patients, to 40 per cent above the normal by feeding glycine, while other amino-acids were without effect in this respect.

On repeating these experiments three years later, Thomas, Milhorat and Techner (9) found that the patients definitely improved when the administration of glycine was continued for some length of time, and they suggested that this beneficial effect might be explained by assuming that a reduced ability to synthesize glycine was an essential point in the pathogenesis of the disease. This would imply that glycine, introduced from without, would act as a substitute for the organisms own insufficient production. If glycine be accepted as a precursor of creatine, the theory would explain the raised creatine excretion following glycine administration to these patients.

In their first paper, Brand and coworkers (3) advocated the theory, based upon the SalkowskyWerner-Fosse cyanic acid theory, that creatine might arise from a side reaction between cyanic acid and glycine:

$$
\text { Cyanic acid }+2 \text { glycine }=\text { creatine }+\mathrm{H}_{2} \mathrm{O}+\mathrm{CO}_{2} .
$$

In more recent papers by Brand (1) and by Brand and Harris (2) the theory is somewhat altered. It is still assumed that glycine is involved in the formation of creatine, namely, of its guanidine group, but for special reasons the glutathione, which is known to contain glycine, is put in relation to the process.

Since publication of the study by Thomas and his coworkers (9) many patients suffering from progressive muscular dystrophy have been treated with glycine, and although there is some division of opinion as to the therapeutic effect, most authors confirm Brand's observation as to the raised creatine content in the urine following glycine feeding.

A theory based on the assumption of a defective glycine synthesis is in itself rather surprising, since it is a generally accepted view that glycine, at least, is an amino-acid which the organism itself can synthesize. But naturally the idea could not be dismissed at the outset, that certain individuals did not possess this function, and this deficiency might be the cause of a disorder as grave as progressive muscular dystrophy.

If benzoic acid be given to a person, the main part combines with glycine and is excreted as hippuric acid. This function seems to extend to many members of the animal kingdom (pig, rabbit, guinea pig, man), and to be a very adequate function, allowing great amounts of benzoic acid to be eliminated. McCollum and Hoagland (7) succeeded in showing, with pigs reduced to an endogenous level of protein metabolism, that the formation of hippuric acid could proceed at a constant level of nitrogen excretion, but was accompanied by a great reduction in the excretion of urea. Only when the urea-nitrogen was lowered to 20 per cent of the total nitrogen was the nitrogen excretion increased, indicating an increased breakdown of protein.

In their first studies Brand, Harris, Sandberg and Ringer (3) fed benzoic acid to their patients with progressive muscular dystrophy. The hippuric acid excretion is not mentioned, but they conclude: "The transformation of glycine into creatine was further confirmed by the drop in creatine excretion following benzoic acid and sodium benzoate feeding." In 1933 Harris and Brand (5) write: "It was repeatedly found that the administration of benzoic acid produced a prompt and appreciable decrease in the creatinuria," and this statement is illustrated by a chart. In 1933 Shorr, Richardson and Wolff (8) find, in patients with Graves' disease, a sharp increase in creatine excretion following sodium benzoate 
feeding. With the exception of the above mentioned chart by Harris and Brand (5) none of these authors publishes data in support of their assertions.

In 1933 Freiberg and West (4) published their investigations on the formation of hippuric acid in 3 children with muscular dystrophy, using 3 normal children of corresponding age and weight as controls. The amounts of benzoic acid fed, 0.1 gram per $\mathrm{kgm}$. of body weight, are rather insignificant, but their results show that the patients synthesize hippuric acid, and hence glycine, at the same rate as the normal controls. Their results are collected in Table I, supplemented by my calculations of the hippuric acid that could have been produced from all the benzoic acid ingested, and the amount of glycine present in the hippuric acid excreted.

\section{TABLE I}

Data from Freiberg and West (4). Glycine synthesis in 3 children with progressive muscular dystrophy after benzoic acid feeding

\begin{tabular}{l|c|c|c|c|c|c|c}
\hline \hline & Age & $\begin{array}{c}\text { Body } \\
\text { weight }\end{array}$ & $\begin{array}{c}\text { Ben- } \\
\text { zoic } \\
\text { acid } \\
\text { in- } \\
\text { gested }\end{array}$ & \multicolumn{2}{|c|}{ Hippuric acid } & \multicolumn{2}{|c|}{ Glycine } \\
\cline { 4 - 8 } & & Fears & kgm. & $\begin{array}{c}\text { Calcu- } \\
\text { lated }\end{array}$ & Found & $\begin{array}{c}\text { Calcu- } \\
\text { lated }\end{array}$ \\
\hline Patient 1 & 11 & 34.6 & 3.46 & 4.698 & 5.52 & 1.81 & 2.13 \\
Control 1 & 12 & 36.0 & 3.60 & 4.108 & 5.75 & 1.58 & 2.21 \\
Patient 2 & 9 & 28.6 & 2.86 & 3.214 & 4.56 & 1.24 & 1.76 \\
Control 2 & 8 & 27.2 & 2.72 & 3.050 & 4.35 & 1.18 & 1.67 \\
Patient 3 & 8 & 21.6 & 2.16 & 2.436 & 3.45 & 0.94 & 1.33 \\
Control 3 & 8 & 22.5 & 2.25 & 2.847 & 3.60 & 1.08 & 1.38 \\
\hline
\end{tabular}

As will be seen from Table I, the authors (4) cannot account for all the benzoic acid ingested, but this may be caused partly by the fact, which their curves seem to show, that the excretion did not stop altogether within the time of sampling ( 5 hours). A more serious objection is that these small amounts of benzoic acid cause only very minute amounts of glycine to be produced. If the therapeutic dose for children of this age is about 15 grams per day, the experiment must show that the diseased organism can synthesize amounts of about the same order.

It may likewise be objected that the glycine present in the hippuric acid might have been extracted from the patients own proteins, which contain on an average about four per cent of glycine. To guard against such an objection, it is necessary to determine the nitrogen excretion simultaneously. The organism being without glycine-deposits, such an extraction of glycine from the protein molecules must of necessity mean the total disintegration of the molecules, with consequent increase of nitrogen excretion to a level twenty-five times as great as the nitrogen content of the glycine extracted.

In 1934 Linneweh and Linneweh (6) published their results from feeding benzoic acid to two adult patients with progressive muscular dystrophy. They determined the nitrogen excretion simultaneously with the hippuric acid excretion, and found that the hippuric acid excretion was paralleled by a rise of nitrogen excretion in the urine, corresponding fairly well with the nitrogen content of the hippuric acid. While it must be admitted that their doses of benzoic acid are fairly large, it can only be regretted that in one of their patients the hippuric acid output is rather poor, 22 grams only, while 48 grams should have been expected from the 30 grams of benzoic acid ingested. It might therefore equally well be concluded that the hippuric acid synthesis is impaired in this patient. Their data have been arranged in Table II, together with the supplementary calculations.

TABLE II

Data from Linneweh and Linneweh (6). Glycine synthesis in 2 adult patients with progressive muscular dystrophy after benzoic acid feeding

\begin{tabular}{|c|c|c|c|c|c|}
\hline & \multirow{2}{*}{$\begin{array}{c}\text { Benzoic } \\
\text { acid } \\
\text { ingested }\end{array}$} & \multicolumn{2}{|c|}{ Hippuric acid } & \multicolumn{2}{|c|}{ Glycine } \\
\hline & & Found & $\begin{array}{l}\text { Calcu- } \\
\text { lated }\end{array}$ & Found & $\begin{array}{l}\text { Calcu- } \\
\text { lated }\end{array}$ \\
\hline Control........... & $\begin{array}{l}\text { grams } \\
30 \text { (?) }\end{array}$ & $\begin{array}{c}\text { grams } \\
36\end{array}$ & $\begin{array}{c}\text { grams } \\
48.0\end{array}$ & $\begin{array}{l}\text { grams } \\
13.85\end{array}$ & $\begin{array}{l}\text { grams } \\
18.50\end{array}$ \\
\hline $\begin{array}{l}\text { Patient } 1 \ldots \ldots \ldots \ldots \\
\text { Patient } 1 \ldots \ldots \ldots \ldots\end{array}$ & $\begin{array}{l}16 \\
30\end{array}$ & $\begin{array}{l}25 \\
41\end{array}$ & $\begin{array}{l}25.6 \\
48.0\end{array}$ & $\begin{array}{r}9.60 \\
15.80\end{array}$ & $\begin{array}{r}9.85 \\
18.50\end{array}$ \\
\hline $\begin{array}{l}\text { Patient } 2 \ldots \ldots \ldots \ldots \\
\text { Patient } 2 \ldots \ldots \ldots \ldots\end{array}$ & $\begin{array}{l}16 \\
30\end{array}$ & $\begin{array}{l}18 \\
22\end{array}$ & $\begin{array}{l}25.6 \\
48.0\end{array}$ & $\begin{array}{l}6.92 \\
8.46\end{array}$ & $\begin{array}{r}9.85 \\
18.50\end{array}$ \\
\hline
\end{tabular}

These authors also determined the creatine and creatinine excretion during the experiments, and they conclude that the creatinuria is not reduced after feeding benzoic acid.

As will be seen from these quotations, the literature is contradictory on one point, viz., the question of reduced creatinuria following the 
feeding of benzoic acid, while on another, the synthesis of hippuric acid, no indisputable conclusion can be drawn. It has been the object of the experiments now to be described, to throw further light on these problems.

\section{EXPERIMENTAL}

The experiments were performed on six patients with typical cases of progressive muscular dystrophy, who were admitted to the Department of Nervous Diseases and the Medical Department A of the Rigshospital (Experiment II). ${ }^{1}$ On the day of the experiment and the day preceding, the patients were served a glycine-free diet consisting of milk, cream, butter, eggs, sugar, bread baked from potato meal and whites of egg, and courses prepared from these ingredients with the addition of salt and spices. No attempt was made to make the nitrogen intake constant, because of practical difficulties; and because, after all, the nitrogen excretion very soon proved to be fairly constant.

It was my aim to give the greatest possible amount of benzoic acid during the day of the experiment, in order to get an acceptable amount of glycine synthesized. It was therefore indispensable to determine (Experiment I), the largest dose of benzoic acid (given as sodium benzoate) which could be taken without substantial discomfort, together with the duration of its excretion.

\section{METHOD}

None of the methods described for the determination of hippuric acid seem to be generally accepted, nor do they give very accurate results, as has been shown in the preceding part. I have preferred the method described by Widmark (10), the principle of which is titration of the benzoic acid after extraction with toluol, in which the hippuric acid is almost insoluble. Instead of the large extraction vessels described by Widmark, I used the smaller tubes constructed by Orskov (11) for similar purposes. They possess great practical advantages. From the microburette $0.1884 \mathrm{cc}$. of $0.05 \mathrm{~N} \mathrm{NaOH}$ is measured into one end of the extraction tube (the recipient), while into the other (the dimittent) is measured $0.8 \mathrm{cc}$. of the urine, which has previously been acidified with sulphuric acid to about $0.5 \mathrm{~N}$. The tube is filled up

\footnotetext{
1 I am indebted to the chiefs of the two departments, Professor Dr. med. Viggo Christiansen, and Professor Dr. med. Carl Sonne, for their kind permission to perform these experiments on their patients.
}

with toluol and rocked for four hours. After this extraction, the toluol plus the content of the dimittent is sucked off and a surplus of $0.05 \mathrm{~N} \mathrm{HCl}$ is added to the recipient from a microburette. It is heated on a water bath at 50 to $60^{\circ} \mathrm{C}$., and a current of air is blown through the recipient to expel the carbon dioxide. The acid is then titrated with $0.05 \mathrm{~N} \mathrm{NaOH}$ from the microburette, using phenolphthalein as an indicator.

Each sample of urine was extracted twice, the first time for the determination of "preformed benzoic acid" directly on the acidified urine, the second time for the determination of the "total benzoic acid" after hydrolysis of the hippuric acid.

The heading "preformed benzoic acid" is a purely practical one, as it covers widely different substances, viz., 1 , free benzoic acid; 2 , ester of benzoic acid and glucuronic acid, which disintegrates immediately when sulphuric acid is added; 3 , hippuric acid which, as already mentioned, is not entirely insoluble in toluol; 4 , other acid substances soluble in toluol.

Although the fraction is small in comparison with the hippuric acid fraction, it would seem desirable, from a theoretical standpoint, to determine the single components. The greatest is, no doubt, the hippuric acid, since preliminary experiments had shown it to be so soluble in toluol that a not inconsiderable part would be dissolved, when the urine was rich in it. Next, an attempt was made to determine the ester fraction by employing a titration with Benedict's solution. But it appeared that the "Eigenreduction" of the urine was so considerable in comparison with the small amount of glucuronic acid present that the plan had to be abandoned. The free benzoic acid eludes direct determination, but it is probably rather insignificant in amount. This can be said with certainty about the "other acid substances," since this component cannot be expected to increase after benzoate feeding, and before such feeding the whole fraction of "preformed benzoic acid" is almost negligible. One must, therefore, be content to determine the sum of the components, and to compromise with the inaccuracy introduced by assuming that all the benzoic acid determined as "total benzoic acid" originates from hippuric acid.

"The total benzoic acid" is determined after treating equal amounts of urine with $4 \mathrm{~N} \mathrm{NaOH}$ on a boiling water bath for six hours. The fluid is neutralized with $2 \mathrm{~N} \mathrm{H}_{2} \mathrm{SO}_{4}$, and after acidify- 


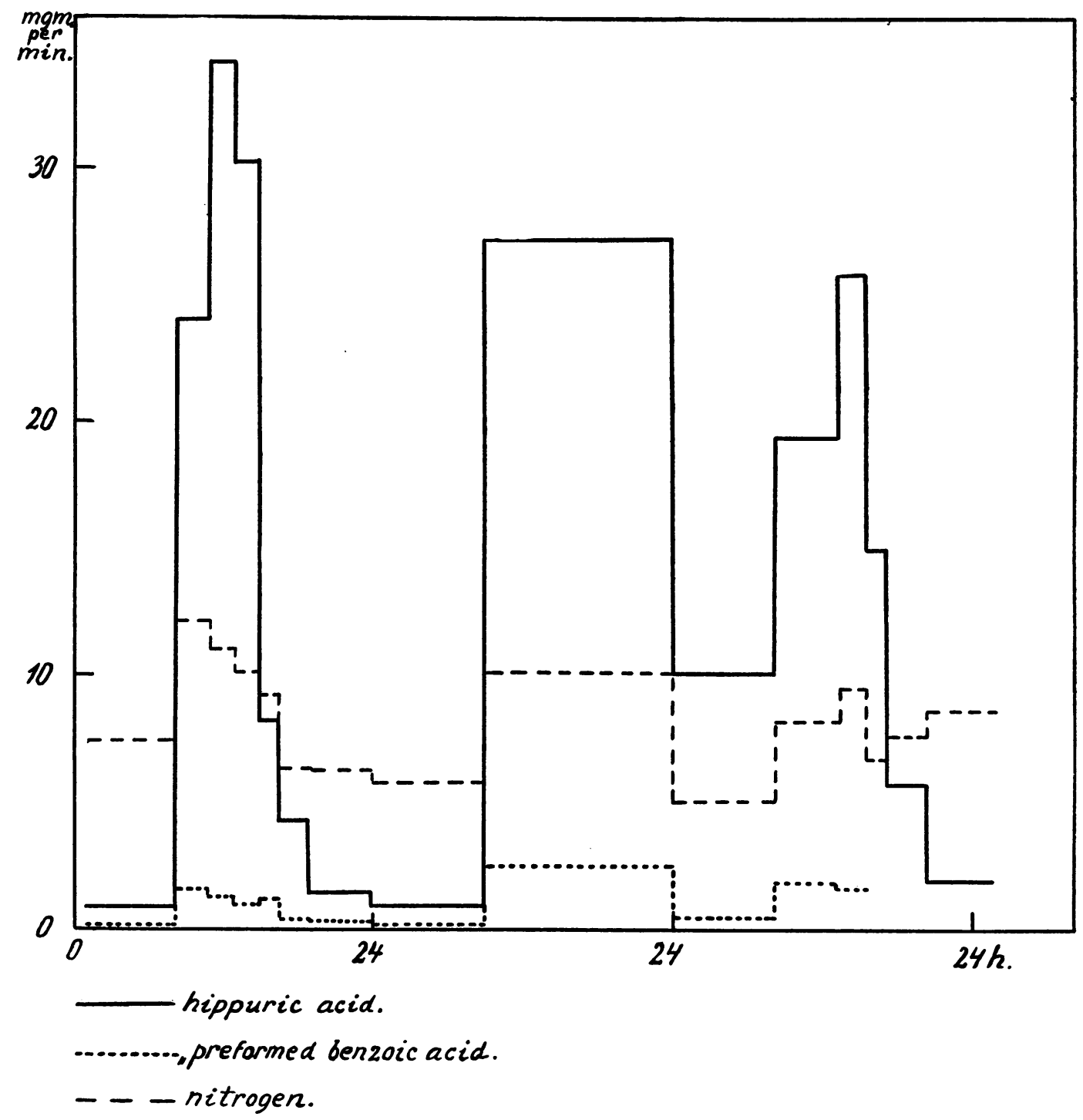

Fig. 1. Synthesis of Hippuric Acid after Feeding Benzoate to a Normal Person during Three Consecutive Days, Together with Nitrogen Excretion.

ing the fluid, the extraction and titration are performed as previously described.

All the analyses were made three times. If one differed essentially from the other two, it was rejected. If they all differed, a new analysis was made.

Experiment $I$. On the first day of the experiment, 10 grams of sodium benzoate were given at $8: 20$ a.m., and as will be seen, the greater part of it was excreted within 6 hours. The next day, 8 grams were given at 9 and 12 a.m. and at 7 p.m. Although rather large amounts were seen to be excreted during the following night, a new dose of 10 grams on the third day showed that the ability to synthesize hippuric acid was still unimpaired. During the three days of the experiment, 44 grams of sodium benzoate were taken (corresponding to 39.7 grams of benzoic acid), and in all 38.68 grams of "total benzoic acid" were excreted, equalling 61.8 grams of hippuric acid, while 59.6 grams should have been expected. This corresponds to a glycine synthesis of 21.4 grams.

The elevations in the nitrogen curve are probably due to the nitrogen contained in the hippuric acid, although they are not greater than might have been expected from the food intake during the daytime.

After the ingestion of 10 grams of sodium benzoate dissolved in water, a slight but rather disagreeable itch is felt in the throat, but it soon disappears. Within ten minutes, a sensation of heat, tingling, and pulsation is felt in the head and skin, accompanied by a transitory xanthopsia. These symptoms all subside within an hour. There is no nausea. 
TABLE III

Benzoate feeding to 6 patients with progressive muscular dystrophy

\begin{tabular}{|c|c|c|c|c|c|c|c|c|c|c|c|c|c|}
\hline \multirow{2}{*}{$\begin{array}{c}\text { Pa- } \\
\text { tient } \\
\text { num- } \\
\text { ber }\end{array}$} & \multirow[b]{2}{*}{ Sex } & \multirow[b]{2}{*}{ Age } & \multirow[b]{2}{*}{ Date } & \multirow{2}{*}{$\begin{array}{l}\text { Benzoic } \\
\text { acid in- } \\
\text { gestion† }\end{array}$} & \multicolumn{2}{|c|}{$\begin{array}{l}\text { Benzoic acid } \\
\text { excreted }\end{array}$} & \multirow{2}{*}{$\begin{array}{l}\text { Hippuric } \\
\text { acid ex- } \\
\text { creted }\end{array}$} & \multicolumn{2}{|c|}{ Glycine calculated } & \multirow{2}{*}{\multicolumn{2}{|c|}{$\begin{array}{c}\text { Total nitrogen } \\
\text { excreted }\end{array}$}} & \multirow{2}{*}{$\begin{array}{l}\text { Crea- } \\
\text { tinine } \\
\text { total }\end{array}$} & \multirow{2}{*}{$\begin{array}{l}\text { Crea- } \\
\text { tine } \\
\text { total }\end{array}$} \\
\hline & & & & & & & & From & From & & & & \\
\hline & & years & 1995 & grams & grams & grams & $\mid \begin{array}{c}\text { mgm. per } \\
\text { minute }\end{array}$ & grams & grams & grams & $\left|\begin{array}{c}\text { mgm. per } \\
\text { minute }\end{array}\right|$ & $m g m$. & $m g m$. \\
\hline 1 & $\mathbf{M}$ & 16 & $\begin{array}{l}\text { August } 26 \\
\text { August } 27 \\
\text { August } 28^{*}\end{array}$ & $\begin{array}{c}0 \\
25.4 \\
0\end{array}$ & $\begin{array}{l}0.10 \\
3.27 \\
0.08\end{array}$ & $\begin{array}{r}1.12 \\
20.40 \\
0.34\end{array}$ & $\begin{array}{r}1.24 \\
22.60 \\
1.81\end{array}$ & $\begin{array}{c}0 \\
15.6 \\
0\end{array}$ & $\begin{array}{r}0.69 \\
12.55 \\
0.21\end{array}$ & $\begin{array}{r}8.76 \\
11.40 \\
2.18\end{array}$ & $\begin{array}{l}6.1 \\
7.9 \\
7.3\end{array}$ & $\begin{array}{l}404 \\
486\end{array}$ & $\begin{array}{l}555 \\
810\end{array}$ \\
\hline 2 & $\mathbf{M}$ & 24 & $\begin{array}{l}\text { August } 23 \\
\text { August } 24 \\
\text { August } 25^{*}\end{array}$ & $\begin{array}{c}0 \\
25.4 \\
0\end{array}$ & $\begin{array}{l}0.25 \\
4.44 \\
0.06\end{array}$ & $\begin{array}{r}2.00 \\
22.80 \\
0.15\end{array}$ & $\begin{array}{r}2.23 \\
25.30 \\
0.78\end{array}$ & $\begin{array}{c}0 \\
15.6 \\
0\end{array}$ & $\begin{array}{r}1.23 \\
14.00 \\
0.89\end{array}$ & $\begin{array}{r}10.80 \\
15.50 \\
1.52\end{array}$ & $\begin{array}{r}7.5 \\
10.8 \\
5.1\end{array}$ & $\begin{array}{r}891 \\
1050 \\
991\end{array}$ & $\begin{array}{l}612 \\
570 \\
370\end{array}$ \\
\hline 3 & $\mathbf{F}$ & 10 & $\begin{array}{ll}\text { September } & 3 \\
\text { September } & 4 \\
\text { September } & 5\end{array}$ & $\begin{array}{l}0 \\
8.5 \\
0\end{array}$ & $\begin{array}{l}0.32 \\
0.62 \\
0.10\end{array}$ & $\begin{array}{l}0.61 \\
8.20 \\
0.38\end{array}$ & $\begin{array}{l}0.68 \\
9.10 \\
0.42\end{array}$ & $\begin{array}{l}0 \\
5.2 \\
0\end{array}$ & $\begin{array}{l}0.38 \\
5.04 \\
0.23\end{array}$ & $\begin{array}{l}1.89 \\
3.11 \\
2.55\end{array}$ & $\begin{array}{l}1.3 \\
2.2 \\
1.8\end{array}$ & & \\
\hline 4 & $\mathbf{M}$ & 34 & $\begin{array}{l}\text { August 17 } \\
\text { August 18 } \\
\text { August 19* }\end{array}$ & $\begin{array}{c}0 \\
25.4 \\
0\end{array}$ & $\begin{array}{l}0.20 \\
3.72 \\
0.02\end{array}$ & $\begin{array}{r}0.73 \\
22.70 \\
0.14\end{array}$ & $\begin{array}{r}0.81 \\
25.20 \\
0.75\end{array}$ & $\begin{array}{c}0 \\
15.6 \\
0\end{array}$ & $\begin{array}{r}0.45 \\
13.95 \\
0.86\end{array}$ & $\begin{array}{r}6.73 \\
10.40 \\
1.37\end{array}$ & $\begin{array}{l}4.7 \\
7.2 \\
4.6\end{array}$ & $\begin{array}{l}1400 \\
1370 \\
1030\end{array}$ & $\begin{array}{l}260 \\
222 \\
108\end{array}$ \\
\hline 5 & $\mathbf{M}$ & 21 & $\begin{array}{cc}\text { April } & 6 \\
\text { April } & 7 \\
\text { April } & 8\end{array}$ & $\begin{array}{c}0 \\
20.0 \\
0\end{array}$ & $\begin{array}{l}0.39 \\
3.40 \\
0.27\end{array}$ & $\begin{array}{r}1.77 \\
18.62 \\
1.02\end{array}$ & $\begin{array}{r}1.96 \\
20.30 \\
1.13\end{array}$ & $\begin{array}{c}0 \\
12.0 \\
0\end{array}$ & $\begin{array}{r}1.09 \\
11.45 \\
0.63\end{array}$ & $\begin{array}{r}10.75 \\
12.33 \\
9.75\end{array}$ & $\begin{array}{l}7.5 \\
8.6 \\
6.8\end{array}$ & $\begin{array}{l}481 \\
656 \\
549\end{array}$ & $\begin{array}{l}305 \\
702 \\
403\end{array}$ \\
\hline 6 & $\mathbf{M}$ & 34 & $\begin{array}{l}\text { October } 22 \\
\text { October } 23 \\
\text { October } 24\end{array}$ & $\begin{array}{c}0 \\
25.4 \\
0\end{array}$ & $\begin{array}{l}0.27 \\
1.79 \\
0.55\end{array}$ & $\begin{array}{r}0.98 \\
19.20 \\
1.77\end{array}$ & $\begin{array}{r}1.10 \\
21.30 \\
1.96\end{array}$ & $\begin{array}{c}0 \\
15.6 \\
0\end{array}$ & $\begin{array}{r}0.60 \\
11.80 \\
1.09\end{array}$ & $\begin{array}{l}7.56 \\
9.00 \\
7.00\end{array}$ & $\begin{array}{l}5.3 \\
6.3 \\
4.9\end{array}$ & $\begin{array}{l}578 \\
516 \\
559\end{array}$ & $\begin{array}{r}720 \\
1063 \\
962\end{array}$ \\
\hline
\end{tabular}

* Only the urine from the first five hours (7 to 12 a.m.) was collected for determination of benzoic acid.

† Given as sodium benzoate.

Experiment II. Table III shows that the patients excrete $80,90,97,90,93$ and 76 per cent respectively of the benzoic acid ingested, thereby producing glycine in amounts varying from 11 to 14 grams, amounts which are fairly comparable with the therapeutic doses of 15 to 30 grams a day.

The nitrogen excretion shows only slight variations, although there seems to be a rise on the day of benzoate feeding.

Since all the patients show essentially the same features in the experiment, we might, as an example, subject $\mathrm{Pa}$ tient Number 2 to a closer examination. On the day of the experiment he excretes 14 grams of glycine, with a nitrogen content of 2.61 grams. If this amount of glycine had been taken from a protein molecule containing four per cent of glycine, while the rest of the molecule had been metabolized, we should have expected the nitrogen content of the urine to rise 25 times 2.61 grams, viz., 65 grams. As the increase is only 4.7 grams, which is but slightly more than is contained in the glycine synthesized, it must be concluded that all the nitrogen of the protein molecules which the organism liberates for this purpose, can be utilized in the synthesis of glycine; in other words, that a true synthesis is going on. This result is in good agreement with McCollum and Hoagland (7), as well as with Linneweh and Linneweh (6).

A study of the excretion of creatine and creatinine does not lend any support to the view held by Brand and coworkers $(1,3,5)$, that creatinuria is lowered after benzoate feeding. The creatinuria shows fluctuations during the three days of the experiment similar to those usual in these patients. In some cases it is higher on the day of benzoate feeding than on the day before and after, in other cases it is lower.

\section{CONCLUSIONS}

The experiments show that six patients with progressive muscular dystrophy can synthesize almost unlimited amounts of glycine for use in the synthesis of hippuric acid.

From this the conclusion is drawn that progressive muscular dystrophy cannot be caused by a defective synthesis of glycine, and that the beneficial effect of glycine treatment cannot be due to glycine acting as a supplement to the organisms. own insufficient production as held by Thomas. and coworkers (9).

The experiments showed no reduction of creatinuria when benzoate was fed, so that this ob- 
servation does not support the hypothesis that creatine is synthesized from glycine.

\section{SUMMARY}

1. A critical account is given of experiments showing the synthesis of glycine in patients with progressive muscular dystrophy.

2. The results of benzoate feeding on six patients suffering from progressive muscular dystrophy are recorded together with similar experiments on one normal subject.

3. The experiments show that the patients are capable of synthesizing glycine equal to the usual therapeutic doses.

\section{BIBLIOGRAPHY}

1. Brand, Erwin, Congenital anomalies of metabolism with special reference to cystinuria and myopathies. Bull. New York Acad. Med., s. 2, 1934, 10, 289.

2. Brand, E., and Harris, Meyer M., Some aspects of intermediary protein metabolism. Science, 1933, 77, 589.

3. Brand, E., Harris, M. M., Sandberg, M., and Ringer, A. I., Studies on the origin of creatine. Am. J. Physiol., 1929, 90, 296.

4. Freiberg, I. H., and West, E. S., Glycine synthesis in pseudohypertrophic muscular dystrophy. J. Biol. Chem., 1933, 101, 449.

5. Harris, M. M., and Brand, E., Metabolic and therapeutic studies in the myopathies, with special reference to glycine administration. J. A. M. A., 1933, 101, 1047.

6. Linneweh, W., and Linneweh, F., Zur Frage des Glykokollmangels und der Glykokolltherapie bei progressiver Muskeldystrophie. Deutsches Arch. f. klin. Med., 1934, 176, 526 .

7. McCollum, E. V., and Hoagland, D. R., Studies of the endogenous metabolism of the pig as modified by various factors. III. The influence of benzoic acid on the endogenous nitrogen metabolism. J. Biol. Chem., 1913, 16, 321.

8. Shorr, E., Richardson, H. B., and Wolff, H. G., The nature of the muscular weakness in Graves' disease. J. Clin. Invest. (Proc.), 1933, 12, 966.

9. Thomas, K., Milhorat, A. T., and Techner, F., Untersuchungen über die Herkunft des Kreatins. Ein Beitrag zur Behandlung progressiver Muskelatrophien mit Glykokoll. Ztschr. f. physiol. Chem., 1932, 205, 93.

10. Widmark, E. M. P., Bestimmung freier und gebundener Benzoesäure mit der Schaukelextraktionsmethode. Biochem. Ztschr., 1926, 179, 263.

11. Orskov, S. L., Eine Mikromethode zur Bestimmung von ätherlöslichen organischen Säuren im Blute. Biochem. Ztschr., 1928, 201, 22. 